\title{
Complications of Varicella in Healthy Children: Is It Increasing?
}

\section{Sağlıklı Çocuklarda Suçiçeği Komplikasyonu: Artıyor mu?}

\author{
Güldane Koturoğlu1, Zafer Kurugöl1, Oya Halıcıoğlu2, Ilker Devrim3, Fadıl Vardar1 \\ ${ }^{1}$ Ege University Faculty of Medicine, Department of Pediatrics, Izmir, Turkey \\ 2 Tepecik Education and Research Hospital, Izmir, Turkey \\ ${ }^{3}$ Behçet Uz Children's Hospital, Izmir, Turkey
}

\begin{abstract}
Aim: Varicella is a common and self-limiting disease caused by the varicella zoster. However it may cause severe morbidity and mortality, due to complications in healthy children. These complications can be prevented by vaccination. The aim of this study was to determine the type of complications of varicella in hospitalized children. Also these data were compared with the study carried out in 2005 and changes in the varicella hospitalizations were analyzed to obtain the necessary data for the study of the vaccine.

Materials and Methods: A retrospective study involving 262 children hospitalized for complications due to varicella between January 2005 and December 2009 was carried out. Incidence and clinical spectrum of complications and their age and seasonal variations related distribution was analyzed.

Results: We identified 262 children hospitalized for complications of varicella. Fourteen children with immune deficiency or on immunosuppressive treatment were excluded. The majority of varicella complications occurred in children under 5 years of age. The most common complications were infectious complications (41.9\%). Thereafter, neurologic complications $(35.6 \%)$ and hematological complications were seen $(3.6 \%)$. The seasonal distribution of complications associated with varicella had a higher incidence in January (21.4\%). Three patients died due to these complications. Conclusion: Complications of varicella were more frequent than previously reported. Also mortality rates were higher than those in the previous study. Varicella can be accompanied by severe complications and death in immunologically healthy children. In this study, the importance of varicella vaccination was emphasized again. The Journal of Pediatric Research 2015;2(2):74-7

Key words: Varicella, complications, children
\end{abstract}

Conflicts of Interest: The authors reported no conflict of interest related to this article.

\section{ÖZET}

Amaç: Suçiçeği sık görülen ve kendi kendini sınıllayan bir hastalıktır. Ancak sağ|ıklı çocuklarda ortaya çıkabilecek komplikasyonlarla ciddi mortalite ve morbiditeye neden olabilmektedir. Aslında bu komplikasyonlar aşı ile önlenebilir. Bu çalışma ile suçiçeği komplikasyonu nedeni ile hastaneye yatıılan hastaların değerlendirilmesi ve 2005 ylında yapılan çalışma ile karşılaştıılarak komplikasyon sıklığının araşıııııması planlandı.

Gereç ve Yöntem: Ocak 2005-Aralık 2009 tarihleri arasında suçiçĕgi komplikasyonu nedeni ile hastaneye yatıılan 262 çocuk hasta çalışmaya alındı. Komplikasyon tipleri ve mevsimsel dağlımları incelendi.

Bulgular: Çalışmaya 262 hasta alındı ancak altta yatan immün yetmezliği olan veya immünsuprese tedavi alan 14 hasta çalışmadan çıkarıldı. Komplikasyonlar sıklıkla 5 yaş altındaki çocuklarda görüldü. En yaygın komplikasyon enfeksiyöz komplikasyonlar idi bunu nörolojik ve hematolojik komplikasyonlar takip etmekteydi. Mevsimsel dağılıma bakıldığında komplikasyonlar ocak ayında pik yapmaktaydı. Üç hasta bu komplikasyonlar nedeni ile kaybedildi.

Sonuç: Suçiçeği komplikasyonları sanıldığından daha sık görülmektedir. Önceki çalışma ile kıyaslandığında mortalite oranları daha fazladır. Suçiçeği komplikasyonları sağıkı çocuklarda ciddi komplikasyonlara ve ölümlere neden olabilmektedir. Bu çalışma ile rutin suçiçeği aşılamasının önemi bir kez daha vurgulanmıştır. The Journal of Pediatric Research 2015;2(2):74-7

Anahtar kelimeler: Suçiçeği, komplikasyon, çocuk

Çıkar Çatışması: Yazarlar bu makale ile ilgili olarak herhangi bir çıkar çatışması bildirmemiştir. 


\section{Introduction}

Varicella is a usually benign and self limiting disease caused by the varicella zoster virus (VZV) (1). More severe forms of the disease and complications are thought to be quite rare in healthy children. However, varicella zoster virus infection can cause severe morbidity and mortality, due to complications involving varicella pneumonia, encephalitis, neurological, hematological and invasive bacterial infections in immunologically healthy children (2-4).

Varicella vaccination may have prevented morbidity and mortality of varicella infection. However, the government did not provide funding for this vaccine during this study period. Decisions on vaccine funding are based on epidemiological information on severe complications from varicella in children (5). But such data are difficult to be obtained in the general population (6).

We conducted a study to determine the type of complications of varicella in hospitalized children. Also these data were compared with the study conducted in 2005 and changes in the varicella hospitalizations were analyzed. The complications of varicella should also be evaluated after vaccination.

\section{Materials and Methods}

The study was conducted at the Departments of Pediatrics of Ege University Medical Faculty; Behçet Uz Children's Hospital, and Tepecik Education and Research Hospital in Izmir, which is the third largest city, and is located in the western part of Turkey.

We reviewed the medical records of children hospitalized for complications of varicella between 1st January 2005 and 31st December 2009. Patient demographics, immune status of the cases, information on varicella complications and the outcome were analyzed. Patients with immunity deficit, such as congenital or acquired immunodeficiency, malignancy, transplanted organ or immunosuppressive treatment within 30 days of admission were excluded.

We defined a varicella complication, an unfavorable evolution of the disease which can become worse in its severity or new pathological changes, or which can become widespread throughout the body or affect other organ systems. Complications were evaluated in three categories: bacterial superinfections, neurological and hematological complications. It was accepted as secondary bacterial infection if characteristic clinical and laboratory findings of bacterial infection were present: cellulitis, abcess, necrotizing fasciitis, sepsis, pneumonia, osteomyelitis. Also, the offending organisms were requested. Neurological complications were defined as altered level of consciousness and/or focal neurological abnormality, together with an abnormal electroencephalogram and/or cerebrospinal fluid. It was accepted as hematological complication if clinical and laboratory diagnosis was thrombocytopenia, anemia, granulocytopenia or venous thrombosis.

\section{Results}

During a-5-year period, 262 children were hospitalized due to varicella complications. Fourteen children were excluded; 10 patients had malignancy, 4 patients had received immunosupressive treatment. A total of 248 patients were analyzed.

The seasonal distribution of complications associated with varicella had a higher incidence in winter, especially in January $(21.4 \%)$, and spring.

There was a slight male predominance with 139 (56\%) boys and 109 (44\%) girls. The majority of varicella complications occured in children less than 5 years of age. The median age of the cases with varicella complications was 3 years. Age varied according to the type of complications (Figure 1): the most common ones were infectious complications $(41.9 \%)$ in children who were under 5 years of age. Thereafter, neurological complications (37.5\%) and hematological complications were seen (3.6\%).

Infectious complications formed the main complication ( $n=104,41.9 \%$; Table I): Pneumonia was observed in 66 children-47 had bacterial, 19 had viral pneumonia (median age: 25 months). Superficial infections, such as impetigo, cellulitis and skin abscess were found in 36 patients. The median age of the children with skin superinfections was 24 months. Septicemia occurred in two patients; staphylococcus aureus and Group A $\beta$ - hemolytic streptococci were isolated from blood culture.

Neurological complications $(n=93,(37.5 \%))$ were the second most common. Febrile seizures occurred in 51 patients (54.8\%), (median age: 2 years), 21 patients had cerebellar ataxia (median age: 5 years) and 21 patients had encephalitis (median age: 5 years). Disseminated varicella infection was seen in $28(11.3 \%)$ patients (median age: 2 years). Of the 9 children with hematological complications; 8 had thrombocytopenia and one patient developed pancytopenia.

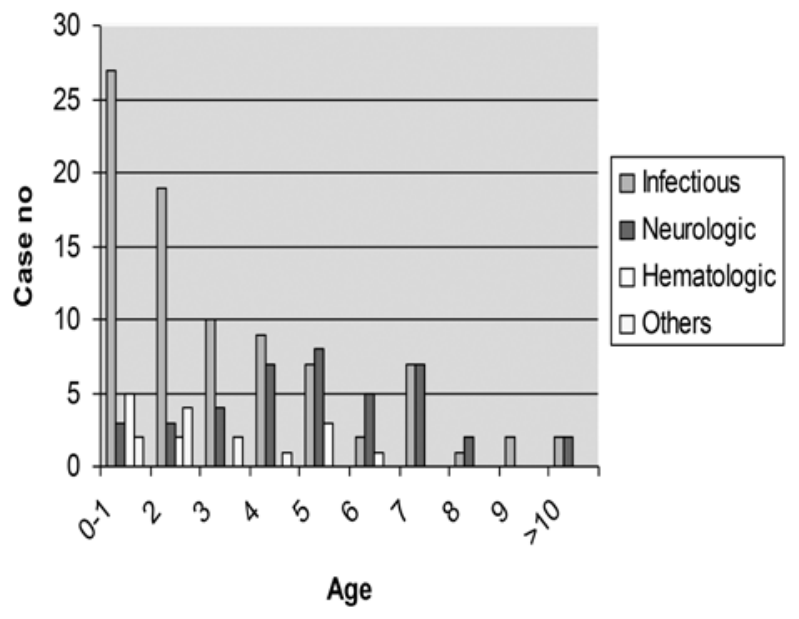

Figure 1. Age distribution according to type of complication 


\begin{tabular}{|l|l|l|}
\hline \multicolumn{3}{|c|}{ Table I. Complications among hospitalized patients for varicella } \\
\hline Complications & 104 & 41.9 \\
\hline Infectious & 66 & 26.6 \\
Pneumonia & 36 & 14.5 \\
Superficial infections & 2 & 0.81 \\
Septicemia & 2 & 37.5 \\
\hline Neurologic & 93 & 20.6 \\
Febril seizures & 51 & 8.46 \\
Encephalitis & 21 & 8.46 \\
Cerebellar ataxia & 21 & 3.62 \\
\hline Hematologic & 9 & 3.22 \\
Thrombocytopenia & 8 & 0.40 \\
Pancytopenia & 1 & 16.9 \\
\hline Others & 42 & 11.3 \\
Disseminated varicella & 28 & 4.03 \\
Varicella pneumonia & 10 & 1.61 \\
Hepatitis & 4 &
\end{tabular}

The median lenght of hospital stay was 5 days (1-55 days). Five patients $(2.1 \%)$ were admitted to the intensive care unit. Three patients died during the study period. Of these, one had purpura fulminans, one had pneumonia and one had encephalitis. Reye syndrome was not reported during the period of observation.

\section{Discussion}

Although varicella is an often benign and self-limiting childhood desease, it can be associated with a variety of serious and potentially fatal complications $(1,7)$. These complications can be prevented by vaccination. Although varicella vaccine has been available in Turkey for many years, it has been routinely used for two years. However, varicella vaccination wasn't used routinely in this study period. Decision-making about the introduction of a new vaccine in a national immunization program is complex and comprehensive data are needed for varicella complications (8). The present study provides epidemiological and clinical data on complications of varicella in children in Izmir, Turkey and compares it with the study conducted in 2005 so that changes in the varicella hospitalizations could be analyzed.

Varicella complications are believed to be rare in immunologically healthy children. However, recent studies have reported that most patients with varicella complications had no severe underlying immunocompromising conditions $(7,9)$. According to a previous study, 192 children were hospitalized due to varicella complications and only $7 \%$ of the present patients with varicella complication were immunocompromised (6). Similarly, most patients (94.7\%) in this study had no preexisting illness. These data show that varicella can lead to serious complications in immunologically healthy children.
In epidemiological studies, varicella complications occurred more frequently in children younger than 10 years $(1,7,10)$. In our study, varicella complications occurred in children younger than those reported in previous studies and the results were similarly to those of the previous studies. The majority of patients were infants and young children. Therefore, varicella vaccine should be given in early childhood in Turkey.

We found that infectious complications were the most frequent specific complications in hospitalized varicella cases in children. In most of the studies, infectious complications were the most frequent ones $(7,11,12)$. Pneumonia $(63.5 \%)$ was the most frequent infectious complication. Risk factors for pneumonia may include poor nutrition and poor socioeconomic conditions. Bacterial skin infections rate was $36.5 \%$. Possible explanations for this may include the use of topical agents and/or nonsteroidal anti-inflammatory drugs (13).

Neurological complications were the second most common (35.5\%). This result is similar to our previous study. However, Bonsignori et al. reported increasing hospitalization rates for cases of neurological complications in Tuscany (5). Children with neurological complications, especially those with febrile seizures, encephalitis and cerebellar ataxia, were admitted to the hospital. Children hospitalized for neurological complications were significantly older than those with other complications. These results may be explained by the hypothesis of a specific post-infectious immune response (3). Hematological complications were rare and were found in 9 patients (3.7\%). This result was the same as the previous study. However, in one study hematological complications have been reported as the most common complications (14). Similar to the previous study, duration of hospitalization was 5 days.

In the present study, the complication rates were higher than the previous one. We determined three deaths in this study, so mortality rates were also higher.

\section{Conclusion}

Although the general population perceives varicella as a benign childhood disease, it can be accompanied by severe complications and death in immunologically healthy children. For this reason varicella vaccine is very important in Turkey.

\section{References}

1. Almuneef $\mathrm{M}$, Memish ZA, Balkhy HH, Alotaibi B, Helmy M. Chickenpox complications in Saudi Arabia: Is it time for routine varicella vaccination? Int J Infect Dis 2006; 10:15661.

2. Riaza Gómez M, de la Torre Espí M, Mencía Bartolomé S, Molina Cabañero JC, Tamariz-Martel Moreno A. Complications of varicella in children. An Esp Pediatr 1999; 50:259-62.

3. Rack AL, Grote $V$, Streng $A$, et al. Neurologic varicella complications before routine immunization in Germany. Pediatr Neurol 2010; 42:40-8. 
4. Carapetis JR, Russell DM, Curtis N. The burden and cost of hospitalised varicella and zoster in Australian children. Vaccine 2004; 23:755-61.

5. Bonsignori F, Chiappini E, Frenos S, Peraldo M, Galli L, de Martino M. Hospitalization rates for complicated and uncomplicated chickenpox in a poorly vaccined pediatric population. Infection 2007; 6:444-50.

6. Koturoglu G, Kurugöl Z, Cetin N,et al. Complications of varicella in healthy children in Izmir, Turkey. Pediatr Int 2005; 47:296-9.

7. Ziebold C, von Kries R, Lang R, Weigl J, Schmitt HJ. Severe complications of varicella in previously healthy children in Germany: a 1 year survey.Pediatrics 2001; 108:79.

8. Wagenpfeil S, Neiss A, Banz K, Wutzler P. Empirical data on the varicella situation in Germany for vaccination decision. Clin Microbiol Infect 2004; 10:425-30.

9. Galil K, Brown C, Lin F, Seward J. Hospitalizations for varicella in the United States, 1988 to 1999. Pediatr Infec Dis J 2002; 21:931-5.
10. Finger R, Hughes JP, Meade BJ, Pelletier AR, Palmer CT. Age-specific incidence of chickenpox. Public Health Rep 1994; 109:750-5.

11. Peterson CL, Mascola L, Chao SM, et al. Children hospitalized for varicella: a prevaccine review. J Pediatr 1996; 129:52936.

12. Abarca K, Hirsch T, Potin M, et al. Complications in children with varicella in 4 hospitals in Santiago, Chile: clinical spectrum and estimation of direct costs. Rev Med Chil 2001; 4:397-404.

13. Mikaeloff $Y$, Kezouh A, Suissa S. Nonsteroidal antiinflammatory drug use and the risk of severe skin and soft tissue complications in patients with varicella or zoster disease. Br J Clin Pharmacol 2008; 65:203-9.

14. Elena B, Anna Q, Andrzej K, Elisabetta P, Laura L, Alberto T. Haematological complications in otherwise healthy children hospitalized for varicella. Vaccine 2011; 29:1534-7. 